\title{
Irish government turns its back on science
}

Dublin. After announcing that it would not be funding any new research projects this year, the Republic of Ireland's major grant agency, Eolas, has now found a small amount of cash for its basic research programme. The money will be made available next month. But scientists say it is not sufficient to meet the needs of the research community, and complain that government support for university research remains at rock bottom.

As a result, hopes for building a strong basic research community continue to dwindle in a country with no real science policy and, at less than one per cent of gross national product, one of Europe's lowest levels of spending on research and development. Ireland has no ministry with specific responsibility for science, and major policy initiatives come from industry.

Apart from biomedical research, which is funded by the Ministry of Health, all research is funded by the Ministry for Industry and Commerce. The ministries' funds are distributed through Eolas's basic and strategic research programmes. Researchers are well aware that any grant application should be able to demonstrate a downstream commercial interest; in the case of Eolas, this requires confirmation by a relevant company.

Biomedical research lost nearly half of its funds in 1989 when, government cuts meant that its budget was reduced from IR $£ 2.3$ million to IR $£ 1.3$ million. Since then, spending on research has been climbing back slowly, and is due to reach $£ 1.78$ million this year. But much more is needed, says Vivian O'Gorman, executive director of the Health Research Board.

Funding for Eolas has also been falling, dropping from IR£2.16 million in 1991 to IR£1.85 million in 1993. The latter figure was only just enough to honour continuing commitments, says Martin Lyes, manager of research and technology support at Eolas - hence the agency's announcement in the spring that it was not able to support any new research projects this year. Many scientists were angry that they had wasted time in replying to a call for applications put out by the agency, which closed in January. They have been even more upset that research is being left to stagnate.

John Corish, dean of science at Ireland's oldest university, Trinity College Dublin, says he regrets in particular the freeze on grants for strategic research. "It is a serious blow to the efforts of the universities to bring their research into the market place", he says.

Earlier this month, Eolas announced that an extra IR£150,000 had been found for some basic research projects and will be distributed in September. The money has come from a combination of savings within the agency and contract income. Lyes says the agency has done what it can to help researchers, but that its options are restricted by its limited budget.

Frustration encouraged researchers to join together to form the Irish Research Scientists Association (IRSA) in May this year. The association, which has about 200 members from all over Ireland, plans to lobby against what it describes as the government's 'antiscience' attitude. Particularly painful, its members claim, is the dismissive attitude of the Minister for Commerce and Technology, Seamus Brennan. In June, Brennan was quoted in the Irish Times as saying that the IR $£ 23.4$ million in "structural funds" received by Ireland from the European Communities would be restricted to companies, not to "some pet project in a university".

"The whole need for science has been questioned", complains Michael Hopkins, senior lecturer in physics at Dublin City University and a member of IRSA. He welcomes the reintroduction of new research money from Eolas, but says it is too little;

"IR $£ 150,000$ is completely inadequate to fund the physics, chemistry and biology projects in Ireland". And it also comes too late to be spent this year.

Frustration among scientists is not restricted to low budgets. Researchers also complain that they seldom know what is happening in government circles, either about policy or available money. Requests from IRSA for briefings with both the minister and with Eolas have not been successful.

Yet big changes are in the air. Eolas is being dismantled in October in a merger between industrial agencies. It will be replaced by a body called 'Forfás' which will have two agencies: the Industrial Development Agency, and Forbairt, which will administer the grants currently handled by Eolas.

In Irish, eolas means knowledge and forbairt means development. For researchers, the change in agency names may be seen as a symbol of the reality of their situation.

Alison Abbott

\section{Extra funds for Northern Ireland}

Belfast. Northern Ireland's two universities have received an extra $£ 4.7$ million ( $\$ 7.0$ million) from the British government for the next financial year to supplement the funds they would otherwise have received purely on the basis of their research performance.

Queen's University in Belfast, and the University of Ulster - which is spread over four main campuses - needed the top-up to compensate for their relatively poor performance in the United Kingdom's recent research assessment exercise.

Over the past two years, the UK government has introduced new criteria for funding research through the university funding councils. These now place more emphasis on research performance, and are intended to eliminate the previous practice of basing research funds primarily on the number of undergraduates (see Nature 362, 4; 1993).

Last year, Queen's University received a top-up of nearly $£ 600,000$ and the University of Ulster nearly $£ 1$ million. Without this, the two universities would have seen their funding for research cut by 0.3 per cent and 3.5 per cent, respectively, while total research funds for higher education in the rest of the United Kingdom rose by more than 11 per cent.

This year, the failure of the universities to improve significantly on their overall research performance would have meant that they were hit even harder. But additional money made available through 'Development Research' funds has avoided the need for more cuts.

This money has been allocated by the Northern Ireland Higher Education Coun- cil, on the basis partly of research assessment ratings, but also on whether research funds would improve the economic, social and cultural life in the province, and would make the universities able to qualify for funding from other sources, such as the European Commission, whose grants must be matched with a university's own funds.

The two universities had to apply for the money by presenting broad plans for improving their research infrastructure. Queen's subsequently received an extra $£ 2.93$ million and the University of Ulster $£ 1.75$ million. Each intends to "back winners" by giving most of the money to departments that did well in the research assessment exercise. At Queen's, for example, the physics and electronic engineering departments received top ratings, and will be rewarded with extra funding from the university.

Goodwill is often the victim of hard times. Both universities have benefited from the development research money. But Queen's University also complains that it is being required to subsidize the University of Ulster, which has been faring particularly poorly.

The latter received additional funding from Ulster's limited pool of resources on the basis that, without a 'safety net', its total income would have fallen by more than one per cent, a situation the government has promised to avoid. The higher education council hopes to ease some of the tension between the two universities by giving priority to research projects that promote links between them. 